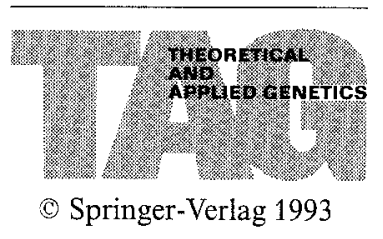

\title{
Development of genetic markers in celery based on restriction fragment length polymorphisms
}

\author{
G. M. Huestis, J. M. McGrath*, and C. F. Quiros \\ Department of Vegetable Crops, University of California, Davis, CA 95616-8746, USA
}

Received April 24, 1992; Accepted June 19, 1992

Communicated by H. F. Linskens

Summary. Linkage relationships are reported for 34 markers in celery (Apium graveolens L. var 'dulce') including 21 RFLP, 11 isozyme, and 2 morphological traits. The mapping was carried out in a cross between celery and an annual accession from Thailand, A143, and based on $F_{2}$ segregation of 136 plants. A total of 318 centiMorgans (cM) are covered by the markers distributed in 8 linkage groups. Probes for the identification of RFLPs were isolated from a celery cDNA library and were also obtained from heterologous sources. EcoRV, EcoRI, and HindIII were the most useful restriction enzymes in uncovering polymorphism. In our cross, $18 \%$ of the cDNA probes were found to be polymorphic for at least one of the enzymes used. Six of the markers showed significant deviations from expected $F_{2}$ ratios.

Key words: RFLP mapping - Isozymes - Apium graveolens

\section{Introduction}

Celery (Apium graveolens L. var 'dulce') is a biennial diploid $(2 \mathrm{n}=2 \mathrm{x}=22)$ species of probable Mediterranean origin. It was used as a condiment and for medicinal purposes by the Greeks as early as $1000 \mathrm{BC}$, and was known to the Chinese, Egyptians, and Romans (de Vilmorin 1950). Today, celery is grown as a leafy vegetable throughout the world, and

\footnotetext{
* Present address: Department of Biology, University of Michigan, Ann Arbor, MI 48109-1048, USA

Correspondence to: G. M. Huestis
}

California is the main producer of the vegetable in the United States.

The genetic base of current U.S. varieties is narrow as they have been derived from a few varieties introduced from Europe early in this century (Quiros et al. 1987b). Few genetic markers have been identified, and little linkage information is available. Isozyme studies were initiated by Arus and Orton (1984) who reported on the linkage relationships of 8 enzyme-coding loci. Quiros et al. (1987a) expanded this work and identified four linkage groups including 9 isozyme loci, a dominant gene for annual habit, and an anthocyanin marker. A moderate germ plasm collection exists, and accessions have been identified that possess characters potentially useful to plant breeders (Trumble and Quiros 1988; Ochoa and Quiros 1989). For example, accessions of $A$. graveolens from Turkey and China have been utilized in breeding plants resistant to Fusarium yellows (Fusarium oxysporum f. apii), an important disease of celery in California (Orton et al. 1984). Ochoa and Quiros (1989) screened Apium species for resistance to late blight (Septoria apiicola Speg.) and found species that displayed varying levels of resistance; $A$. nodiflorum showed the highest resistance though morphologically it is distinct from celery and crosses would be difficult. Both $A$. chilense and $A$. panul showed resistance to Septoria, and crosses between them and celery have been made.

In recent years, restriction fragment length polymorphisms (RFLPs) have increased dramatically the number of chromosomal markers available for plant breeding and genetic studies (Botstein et al. 1980; Tanksley et al. 1989). Celery, with its long generation time, is an ideal candidate for the application of RFLP analysis for early identification of useful genes. The present study was initiated with the aim of increasing the markers in celery based primarily on RFLPs. RFLP markers will help in cultivar development by increasing the efficiency with which useful traits can be introgressed into current cultivars (Young and Tanksley 1989), for gene tagging, and in the analysis of quantitative trait loci. Reported here are the linkage relationships of 21 RFLP loci, 10 isozyme markers, 
and anthocyanin pigmentation, which are grouped in 8 linkage groups.

\section{Materials and methods}

\section{Plant materials}

The species $A$. graveolens exists in three horticultural types, all intercrossable. A pilot study was initiated to access the level of polymorphism within and between the $A$.graveolens horticultural types and two uncultivated Apium species $A$. chilense and $A$. panul (Table 1). For genetic mapping experiments the celery cv 'Tall Utah 52-70R' accession A40 (hereon designated as A40) was crossed with accession A143, an annual accession from Thailand (PI1257228). The latter is characterized by hollow stems with anthocyanin pigmentation, leaves slightly larger though the same general shape as celery, and a tendency to form lateral shoots. From a single $F_{1}$ plant $136 F_{2}$ progeny were generated. For some markers, fewer than 136 plants were scored.

\section{DNA extractions}

For the pilot study, DNA from the six accessions listed in Table 1 was purified on cesium chloride gradients by the method of Fisher and Goldberg (1982) modified by Kianian (1990). For $\mathrm{F}_{2}$ plants, DNA was isolated by the method of Murray and Thompson (1980) as modified by McGrath and Quiros (1991). The DNA was evaluated for size and concentration by running $10 \mathrm{ul}$ on a minigel and making a comparison with DNA of known concentration.

\section{Sources of probes}

A cDNA library was constructed from celery plants that were in the early stages of bolting. RNA was isolated from $8 \mathrm{~g}$ of celery crown tissue by the method of Catala et al. (1983). Poly-A ${ }^{+}$mRNA was selected after two passes of the total RNA preparation over an oligo-T cellulose column, yielding $193 \mathrm{ug}$ of poly- $\mathrm{A}^{+}$mRNA. Integrity of the poly- $\mathrm{A}^{+} \mathrm{mRNA}$ was tested in a wheat germ in vitro translation system (Anderson et al. 1983).

First-strand cDNA synthesis followed the procedure of Murray et al. (1983) using $12 \mathrm{ug}$ of poly- $\mathrm{A}^{+} \mathrm{mRNA}$ and AMV reverse transcriptase. Second-strand synthesis was done by the method of Guber and Hoffman (1983). Reaction products of both the first and second stands were monitored by alkaline agarose gel electrophoresis (Maniatis et al. 1982). The average size of the cDNA was approximately $650 \mathrm{bp}$. Plasmid pBR322 was G-tailed at the unique PstI site, and the cDNA was C-tailed using terminal transferase. Homopolymeric tailing, annealing, and transformation of $\mathrm{CaCl}_{2}$-prepared $\mathrm{DH} 5$ competent cells were performed according to Maniatis et al. (1982). The size of the cDNA library was $3 \times 10^{4}$ clones.

For probe preparation, bacteria containing cDNA clones were grown in LB medium containing $0.1 \%$ glucose and $15 \mathrm{ug} / \mathrm{ml}$ tetracycline. Plasmid DNA was extracted by the rapid alkaline method of Birnboim and Doly (1979), digested with PstI, and run on low-melt agarose; the insert was subsequently recovered. Clones which had inserts greater than $400 \mathrm{bp}$ were selected and hexamer labeled with $\left[{ }^{32} \mathrm{P}\right]$-dCTP (Feinberg and Vogelstein 1984). Random cDNA clones were given alphanumeric designations.

For additional DNA markers, clones of known genes were used as heterologous probes. The genes encoding chalcone synthase (CHS) and phenylalanine ammonia-lyase (PAL) were derived from parsley (Chappell and Hahlbrock 1984). Two ribosomal RNA probes were used, pTA71, which hybridizes to the coding region of $18 \mathrm{~S}-28 \mathrm{~S}$ rDNA (Gerlach and Bedbrook 1979), and 5S, also from wheat (Gerlach and Dyer 1980). The photosystem II chlorophyll a/b binding protein gene type I (pL8) was from tomato (Pichersky et al. 1985).

\section{Restriction digests, electrophoresis, and Southern analysis}

For the pilot study, we used eight clones randomly selected from the celery cDNA library, probes PAL and CHS, and pTA71 (see above for description of heterologous probes). These probes were hybridized to filters containing DNA from the six Apium species (Table 1) singly digested with six restriction enzymes, BamHI, EcoRI, EcoRV, HindIII, SstI, and XbaI. For $\mathrm{F}_{2}$ blots, EcoRI, EcoRV and HindIII were employed.

Digests were run on $1 \%$ agarose gels containing $1 \mathrm{ug} / \mathrm{ml}$ ethidium bromide in $1 \times$ TAE $(40 \mathrm{~m} M$ TRIS-acetate, $1 \mathrm{~m} M$ EDTA, ph 8.0) with 5 ug DNA per lane; $20 \mathrm{ng}$ of $1-\mathrm{kb}$ ladder (BRL) was used as a size marker. Gels were blotted onto Zetaprobe nylon membranes following the manufacturers specifications (Biorad).

Filters were hybridized in a solution containing $5 \times \mathrm{SSC}$, $5 \times$ Denhardt's, $25 \mathrm{mM} \mathrm{NaPO}{ }_{4} \mathrm{pH} \quad 7.0,0.5 \%$ SDS, $10 \mathrm{mM}$ EDTA pH 8.0 and $0.5 \%$ dextran sulfate, at $65^{\circ} \mathrm{C}$ for $15-20 \mathrm{~h}$, washed in $1.0 \%$ SDS, $2 \times \mathrm{SSC}$ and $0.1 \%$ pyrophosphate for the first $15 \mathrm{~min}$ and then $30 \mathrm{~min}$ at room temperature, followed by one to two washes at $65^{\circ} \mathrm{C}$ in $1 \% \mathrm{SDS}, 0.1 \times \mathrm{SSC}$, and $0.1 \%$ pyrophosphate. During the final wash, the blots were monitored with a Geiger counter until the non-specific background was no longer detected. Exposure of filters was at $-80^{\circ} \mathrm{C}$ for $3-4$ days. Blots were strip washed for reprobing according to the manufacturer's instructions (Biorad).

\section{Electrophoresis of isozymes}

Root tissue from 6-week-old parental, $F_{1}$, and $F_{2}$ plants were assayed for allozymic differences for nine different enzymes: phosphoglucoisomerase (PGI), phosphoglucomutase (PGM), triose-phosphate isomerase (TPI), shikimic acid dehydrogenase (SDH), 6-phosphogluconate dehydrogenate (6PGD), alcohol dehydrogenase $(\mathrm{ADH})$, malate dehydrogenase $(\mathrm{MDH})$, glutamate oxaloacetate transaminase (GOT), and aconitase (ACO). Electrophoresis and isozyme staining protocols were according to Vallejos (1983) and Quiros et al. (1987a).

\section{Morphological characters}

$\mathrm{F}_{2}$ plants were scored for anthocyanin pigmentation $(A)$ at the time of the isozyme assay (6-week-old seedlings). Side shoot formation was scored in mature plants during the first season of growth. Only plants showing prolific side shoots, such as in the A143 parent, were scored as positive. A preliminary designation of Sh was given to this character. At the same time, petioles were assayed as hollow or solid. Annual versus biennial habit $(H b)$ was determined during the first year's growing season in the greenhouse.

\section{Linkage analysis}

Tests for Mendelian segregation and linkage analysis were performed on an IBM PC using the computer program Linkage-1 (Suiter et al. 1983).

\section{Results}

To assess the level of polymorphism within Apium species, six accessions (Table 1 ) were digested with six different restriction enzymes, and Southern blots were 
probed with 11 probes: $8 \mathrm{cDNA}$ clones, PAL, CHS, and pTA71. Nearly all probes showed polymorphism between species (Table 1). Within Apium graveolens, maximum polymorphism was detected between accessions A40 and A143 (Table 1), and these types were used as parents for the inheritance analyses. Restriction enzymes EcoRI, EcoRV, and HindIII were the most useful in disclosing polymorphism among all probe-enzyme combinations and were used exclusively in subsequent analyses.

Table 1. Summary of polymorphism between celery and Apium species based on a survey of 11 clones

\begin{tabular}{lllll}
\hline Species & Common name & UCD accession & Origin & $\begin{array}{c}\text { Polymorphic } \\
\text { clones }^{\mathrm{b}}\end{array}$ \\
\hline $\begin{array}{llll}\text { A. graveolens var dulce } \\
\text { A. graveolens var rapaceum }\end{array}$ & Celery & A040 & USA $^{\mathrm{a}}$ & - \\
A. graveolens var secalinum & Celeriac & A112 & Turkey & $2 / 11$ \\
A. graveolens var secalinum & Smallage & A170 & Germany & $5 / 11$ \\
A. chilense & Annual smallage & A143 & Thailand & $6 / 11$ \\
A. panul & Wild & A073 & Chile & $10 / 11$ \\
\hline
\end{tabular}

a Celery cv 'Tall Utah 5270R', Ferry Morse Seed Co

b Number of clones which were polymorphic between celery and the other plant types for at least one enzyme

Table 2. Segregation ratios, goodness-of-fit tests, and probabilities for loci in the cross A40 $\times 143$

\begin{tabular}{|c|c|c|c|c|c|c|c|c|}
\hline \multirow[t]{2}{*}{ Locus $^{a}$} & \multicolumn{5}{|c|}{ Observed segregation } & \multirow{2}{*}{$\begin{array}{l}\text { Expected } \\
\text { ratio }\end{array}$} & \multirow[t]{2}{*}{$\chi^{2}$} & \multirow[t]{2}{*}{$P$} \\
\hline & A40 allele & & $\mathrm{A} 40 / \mathrm{A} 143$ & & A143 allele & & & \\
\hline$B 02-I$ & 23 & & & (87) & & $3: 1$ & 0.98 & 0.32 \\
\hline$B 22-H$ & 05 & & 10 & & 05 & $1: 2: 1$ & 0.00 & 1.00 \\
\hline B33- $H$ & 17 & & 40 & & 21 & $1: 2: 1$ & 0.46 & 0.79 \\
\hline$B 37-I$ & 19 & & 68 & & 21 & $1: 2: 1$ & 7.33 & 0.03 \\
\hline $\mathrm{C} 22-\mathrm{H}$ & 19 & & 31 & & 22 & $1: 2: 1$ & 1.64 & 0.44 \\
\hline$C 23-V$ & 26 & & 60 & & 29 & $1: 2: 1$ & 0.37 & 0.83 \\
\hline$C 27-V$ & 26 & & 48 & & 24 & $1: 2: 1$ & 0.12 & 0.94 \\
\hline $\mathrm{C} 30-\mathrm{H}$ & 27 & & 49 & & 36 & $1: 2: 1$ & 3.19 & 0.20 \\
\hline C37-I & 28 & & 47 & & 21 & $1: 2: 1$ & 7.33 & 0.03 \\
\hline$D 01-H$ & 36 & & 50 & & 23 & $1: 2: 1$ & 3.48 & 0.14 \\
\hline$D 03-V$ & 16 & & 39 & & 15 & $1: 2: 1$ & 0.94 & 0.62 \\
\hline$D 15-H$ & 39 & & 43 & & 30 & $1: 2: 1$ & 9.20 & 0.01 \\
\hline F19-V & & (75) & & & 28 & $3: 1$ & 0.26 & 0.61 \\
\hline$F 34-V$ & 35 & & 37 & & 31 & $1: 2: 1$ & 8.48 & 0.01 \\
\hline$F 38-V$ & 27 & & 53 & & 23 & $1: 2: 1$ & 0.40 & 0.82 \\
\hline$F 48-H$ & 23 & & 57 & & 21 & $1: 2: 1$ & 1.75 & 0.42 \\
\hline G26-V & 38. & & 42 & & 24 & $1: 2: 1$ & 7.62 & 0.02 \\
\hline$G 28-V$ & 32 & & 53 & & 20 & $1: 2: 1$ & 2.75 & 0.25 \\
\hline G43-I & 31 & & 43 & & 30 & $1: 2: 1$ & 3.13 & 0.21 \\
\hline$C a b 1-V$ & 23 & & & $(87)$ & & $3: 1$ & 0.54 & 0.46 \\
\hline$C a b 2-V$ & & $(72)$ & & & 33 & $3: 1$ & 2.31 & 0.13 \\
\hline$P A L-V$ & 27 & & 54 & & 27 & $1: 2: 1$ & 0.00 & 1.00 \\
\hline $5 S-H$ & & $(74)$ & & & 31 & $3: 1$ & 1.15 & 0.28 \\
\hline$A c o-1$ & 40 & & 61 & & 34 & $1: 2: 1$ & 1.79 & 0.41 \\
\hline$A d h-1$ & 28 & & 71 & & 37 & $1: 2: 1$ & 1.46 & 0.48 \\
\hline Got-1 & 29 & & 69 & & 34 & $1: 2: 1$ & 0.65 & 0.72 \\
\hline$P g i-3$ & 36 & & & $(98)$ & & $3: 1$ & 0.24 & 0.61 \\
\hline$P g m-3$ & 23 & & 80 & & 26 & $1: 2: 1$ & 7.59 & 0.02 \\
\hline$S d h-1$ & 29 & & 67 & & 39 & $1: 2: 1$ & 1.49 & 0.47 \\
\hline$T p i-1$ & 32 & & 79 & & 25 & $1: 2: 1$ & 4.28 & 0.12 \\
\hline$A$ & 42 & & & $(83)$ & & $3: 1$ & 4.93 & 0.03 \\
\hline$H b$ & 33 & & & $(88)$ & & $3: 1$ & 0.33 & 0.56 \\
\hline$S h$ & & $(76)$ & & & 40 & $3: 1$ & 5.56 & 0.02 \\
\hline
\end{tabular}

${ }^{\text {a }}$ Letter suffix to locus symbol indicates enzyme used: I, EcoRI; H, HindIII; V, EcoRV 
A total of $118 \mathrm{cDNA}$ clones were tested for polymorphism between $\mathrm{A} 40$ and $\mathrm{A} 143$, and $18 \%$ of these showed polymorphism with at least one enzyme (examples are shown in Fig. 1a). The majority of clones $(70 \%$, whether polymorphism was detected or not), hybridized to single genomic fragments with at least one restriction digest, suggesting they reside at a single locus in the celery genome. Few clones $(3 \%)$ showed complex patterns with all of the digests which is suggestive of multicopy loci or gene families under the stringency conditions employed here. Locus copy number for the remaining fraction of clones $(27 \%)$ was difficult to estimate solely on the basis of restriction fragment patterns. These results suggest celery contains relatively few duplicate genes.

Inheritance data for RFLP, isozyme, and morphological markers were gathered from an $\mathrm{F}_{2}$ population derived from a single $F_{1}$ individual of the cross A40 $\times$ A143. A total of 33 markers were scored; including $19 \mathrm{cDNA}$ RFLPs. 4 RFLP markers disclosed using probes whose gene function is known, 7 isozyme loci, and 3 morphological characters (Table 2). The majority of these markers could be grouped on 8 of the 11 possible linkage groups of celery (Fig. 3), covering a total of 318 centiMorgans $(\mathrm{cM})$. The average distance between markers was $12 \mathrm{cM}$, with a range in distance of $1-38 \mathrm{cM}$ (Fig. 3). Three loci were unlinked. Occasionally, RFLPs revealed on test blots did not segregate in the $F_{2}$, which indicated that the parents were heterozygous for these markers.

In general, there was no over representation of alleles from either parent when all of the loci were pooled. However, examination of goodness-of-fit values revealed that 7 of the 33 loci segregating in this cross showed deviation from expected Mendelian values. Two loci, D15 and $F 34$ had distorted segregation values at the highly significant level and mapped to the same linkage group separated by a distance of $6 \mathrm{cM}$. Closer inspection showed that both of these loci had greater than expected numbers of the A40 alleles at the expense of heterozygotes.

The rRNA probe pTA71 revealed polymorphism between the cultivated species and the wild species; however, the horticultural types where monomorphic for this probe (Fig. 1a). The two wild species, $A$. chilense and A. panul, shared an identical banding pattern in all digests for this probe.

The 5S rRNA clone was useful in detecting polymorphism between A40 and the A143 parents. When celery accession blots were probed with the clone from this gene, HindIII digests (with the exception of A143) showed a ladder pattern characteristics of highly repeated tandem arrays (Fig. 1a). In DNA cut with $E c o$ RI or $E c o$ RV there was only a single large band

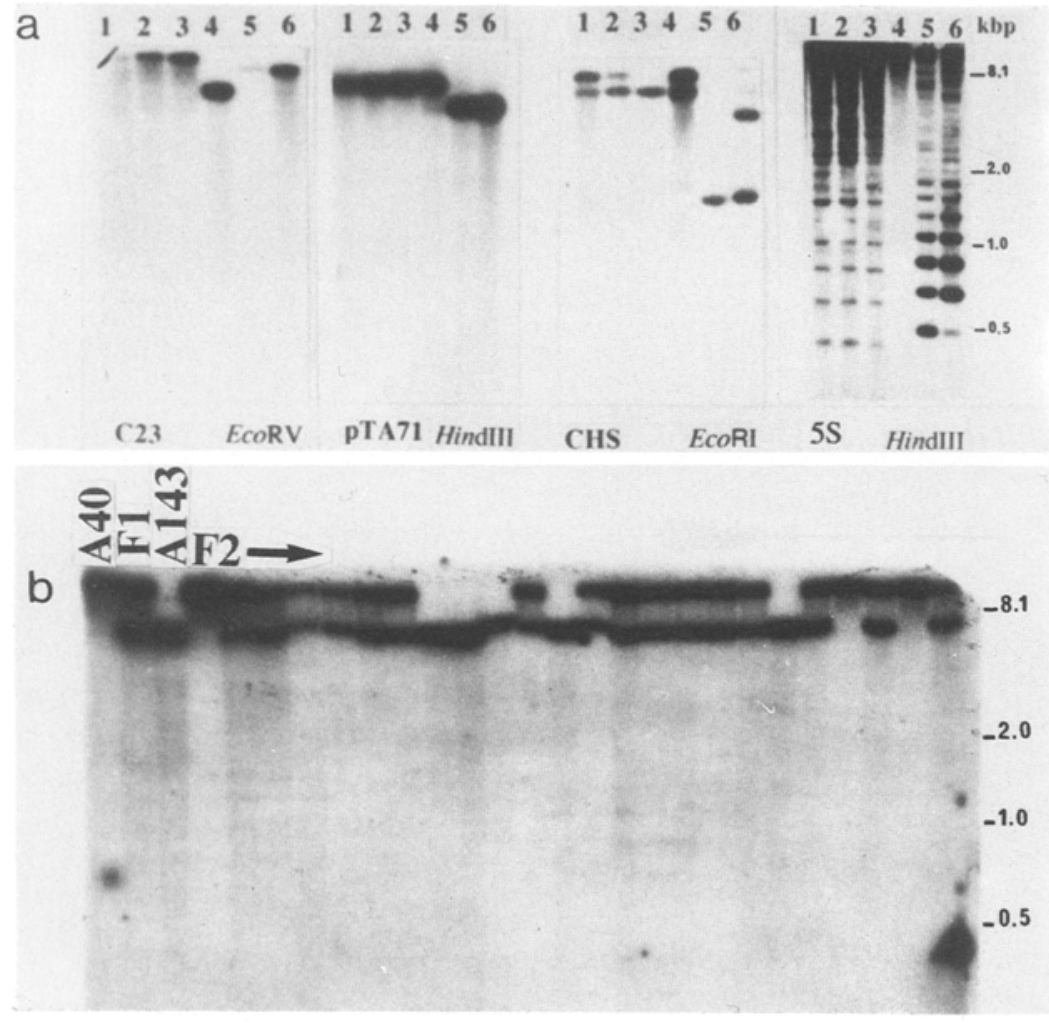

Fig. 1a, b. a Autoradiogram derived from hybridizing probes to DNA of the six plant species used in the initial parental screening. C23 was a single-copy number probe derived from the celery cDNA library; pTA71 and 5S are probes of ribosomal genes; CHS is the cloned chalcone synthase gene. Lane 1 A40, $2 \mathrm{~A} 112,3 \mathrm{~A} 170,4 \mathrm{~A} 143,5 \mathrm{~A} 73,6 \mathrm{~A} 160$ (see materials and methods). b Example of $F_{2}$ segregation of RFLPs detected by the $\mathrm{C} 23$ probe 

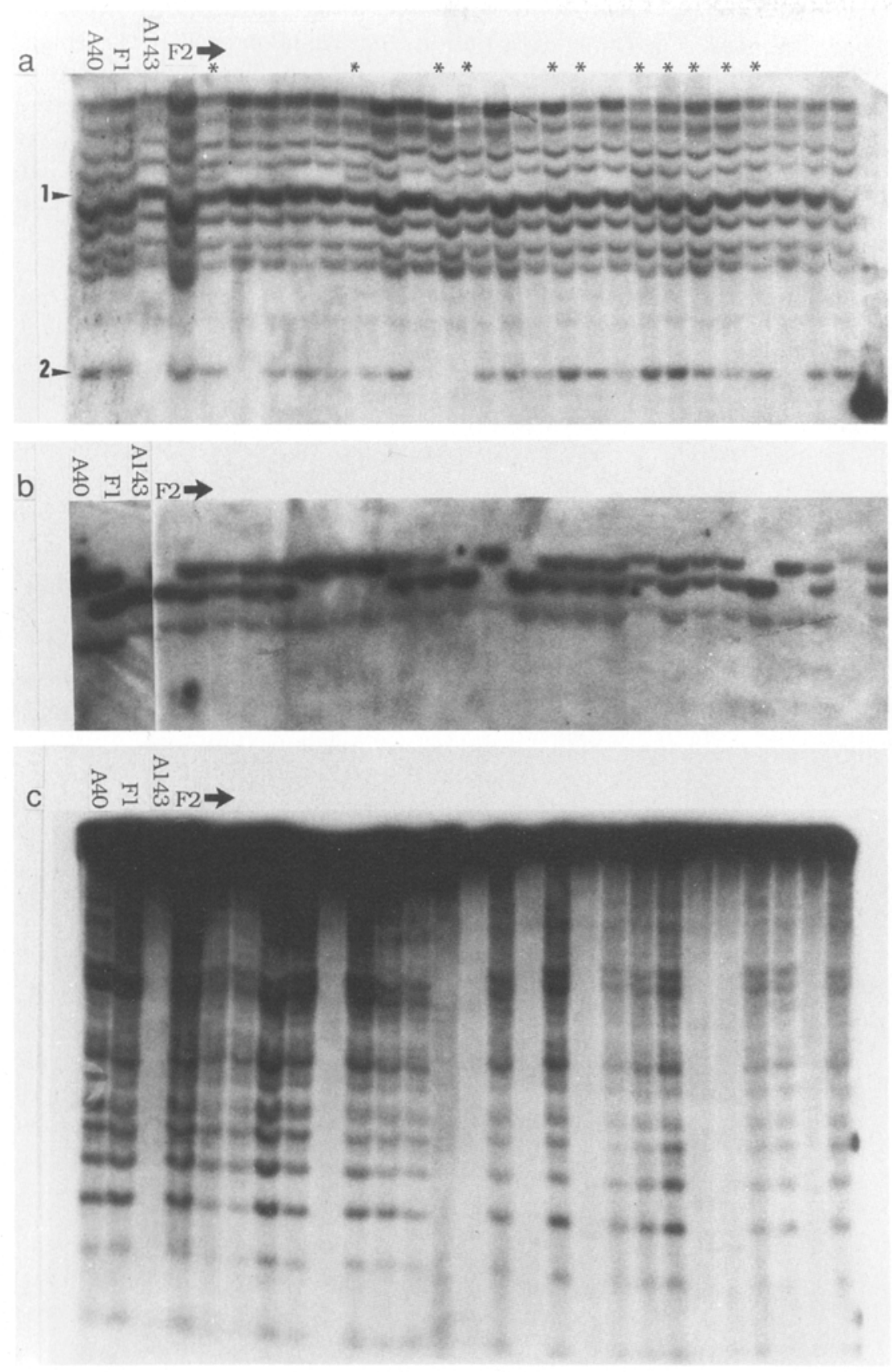

Fig. 2a-c. a Segregation of RFLPs detected by a chlorophyll $a / b$ binding protein gene (pL8). Two bands segregated with null alleles, $c a b-1$ and $c a b-2$, and are indicated by the arrows. Lanes in the $\mathbf{F}_{2}$ with the $c a b-1$ band are indicated by an asterisk for clarity. $\mathrm{b} \mathrm{F}_{2}$ segregation for the phenylalanine ammonia-lyase (PAL) gene. $\mathrm{F}_{2}$ segregation for the $5 \mathrm{~S}$ gene greater than $23 \mathrm{~kb}$, indicating these enzymes had no recognition sites in the 5S DNA. In HindIII digests, restriction fragment differences were observed between the cultivated types and the two wild species, both in repeating unit size and band intensity. A repeat unit of 215 bp was observed in autoradiograms of all Apium graveolens horticultural types except A143, whereas $A$. chilense and $A$. panul both had repeat lengths of 245 bp (Fig. 1a). The two wild species also had more intense signals in the lower-molecular-weight bands, whereas patterns in the cultivated species were most intense in the higher bands. In HindIII digests of A143 only a single band of high-molecular-weight DNA was observed. This polymorphism allowed the $5 S$ gene locus to be mapped (Fig. 2c) to chromosome 3 at a distance of $5 \mathrm{cM}$ from $A d h-1$.

When using the parsley chalcone synthase probe, a one- or two-banded pattern was observed: a lower fixed band and an variable upper band (Fig. 1a). In all of the digests, A40 and A143 were monomorphic for this upper band and CHS was unable to be mapped. PAL, also from parsley, showed polymorphism be- 
tween $\mathrm{A} 40$ and $\mathrm{A} 143$ when digested with $E c o \mathrm{RV}$ and was mapped to group 6 , linked to $B 37$ by $4 \mathrm{cM}$ (Fig. 2b).

The chlorophyll $\mathrm{a} / \mathrm{b}$ binding protein gene (pL8) probe hybridized to $11 E c o$ RV fragments, the only enzyme that revealed polymorphism. Two bands were segregating in our cross with null alleles (Fig. 2a). For this reason, Mendelian segregation was tested for a $3: 1$ ratio. One band, designated $c a b-1$, was linked to the $B 37$ RFLP locus by $4 \mathrm{cM}$, while the other, $c a b-2$, was unlinked to any other marker (Fig. 3).

Two new isozyme markers, aconitase (Aco-1) and triose phosphate isomerase ( $T p i-1)$, were added to the 9 enzyme-coding loci previously characterized by Quiros et al. (1987a). Anthocyanin pigmentation $(A)$, previously loosely linked to the gene for annual habit (Quiros et al. 1987a), was found linked to aconitase by $3 \mathrm{cM}$. Tpi-1 was linked to the RFLP locus $B 33$ by $10 \mathrm{cM}$ (Fig. 3).

The propensity to form side shoots appeared to be a recessive trait. In the $F_{2}, 40$ plants out of 116 had side shoots, while 76 did not. Since greenhouse-grown A 40 was observed to have a low level of side shoots, only $F_{2}$ plants which were prolific producers of side

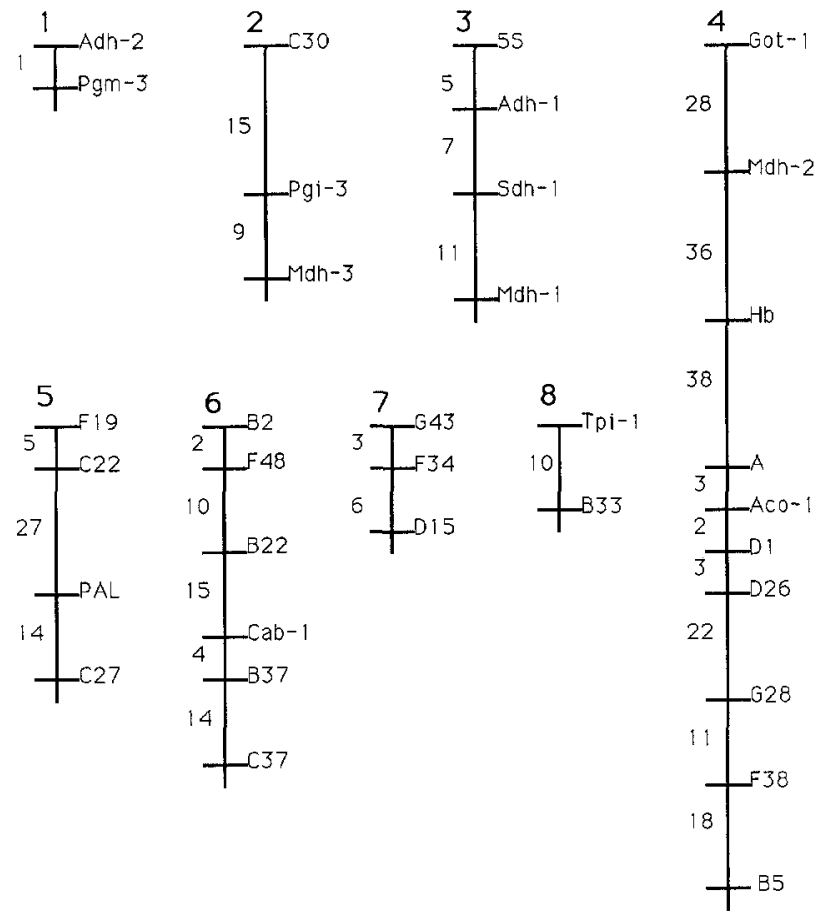

Linkages not detected: $C 23,03, C a b-2$

Fig. 3. Linkage map of celery including RFLP, isozyme, and morphological markers. Map distances are in centiMorgans. The map incorporates the data of Quiros et al. (1987a) shoots were scored as positive. There was, however, a significant deviation from values expected for a single gene hypothesis, and we were unable to map this trait.

Hollow stem is an important character to celery breeders because it is unacceptable in commercial cultivars where a solid stem is desired. Both the A143 parent and the $F_{1}$ had hollow stems, indicating the dominance of this character. In the $\mathrm{F}_{2}$ the degree of hollowness varied: 14 plants had the solid stem of the A40 parent, while 109 had stems with anywhere from a small proportion of the stem hollow to completely hollow like the A143 parent. The data do not fit a one- or two-gene model, and it is likely multiple genes control this trait.

\section{Discussion}

The 4 existing celery linkage groups (Quiros et al. 1987a) have been expanded to 8 and include 21 RFLP markers and 2 previously unreported isozyme loci, aconitase and triose phosphate isomerase. These markers cover a total $318 \mathrm{cM}$ of the celery genome, although it is not known to what extent these 8 linkage groups correspond to the 11 chromosomes of celery. With further mapping some may coalesce into single linkage groups, and new groups should be resolved. RFLP markers mapped to groups 2,3, 4 of Quiros et al. (1987a), with many located on group 4 , the largest linkage group so far (Fig. 3).

Of the clones isolated from the cDNA library $70 \%$ represented single-copy loci based on banding pattern. Since these clones were derived from expressed genes, this observation provides evidence that celery is a true diploid and argues against any recent polyploidization event, because in that case we would expect to see a higher proportion of duplicated genes. Similar findings have been reported in tomato (Bernatzky and Tanksley 1986) and lentil (Havey and Meuhlbauer 1989), and they are in marked contrast to the situation in Brassica (Sloccum et al. 1990; McGrath et al. 1990), where duplicated loci provided evidence for secondary polyploidy of the original diploid genome.

Differences is ladder patterns seen in Southern blots which had been probed with the $5 \mathrm{~S}$ ribosomal RNA gene can be explained either by sequence divergence or methylation in restriction enzyme recognition sites. The two wild species showed more intense signals in lower bands, indicating that more units were cut thereby yielding smaller bands (monomers, dimers, etc.): If all of the repeating units were cut, we would expect to see a single intense monomeric bands the size of the repeating unit. The lack of a ladder banding pattern in A143 digested by HindIII can be explained by the loss of HindIII sites in 5S RNA repeating units, or by methylation, and prevented us from determining 
the size of the unit. HindIII sites are also lacking in the 5S RNA genes of a wide variety of plants including tomato (Lapitan et al. 1991), maize (Mascia et al. 1981), and Matthiola and mung bean (Hemleben and Werts 1988). A143 could have lost HindIII sites during divergence of this plant and the other, cultivated A. graveolens. As all of the other A. graveolens types share a repeating unit of $215 \mathrm{bp}, \mathrm{A} 143$ most likely also has a repeat length of $215 \mathrm{bp}$.

The results of genetic mapping showed that the tandemly repeated 5S RNA genes reside at a single locus. The cluster is located on linkage group $3,5 \mathrm{cM}$ from $A d h-1$. Using in situ hybridization, Appels et al. (1980) found one major location of 5S RNA genes on the chromosomes of wheat, barley, and rye, while Ellis et al. (1988) found three 5S RNA gene locations in pea. Using both in situ hybridization and RFLP mapping similar to our technique, Lapitan et al. (1991) found a single site for the 5SRNA genes in tomato. Interestingly, in tomato the 5S RNA gene cluster maps $26 \mathrm{cM}$ away from a locus coding for the enzyme shikimic acid (Lapitan et al. 1991; Young and Tanksley 1988). In celery, the 5S RNA genes map to a location $12 \mathrm{cM}$ from the $S d h-1$ locus. Whether this represents an ancestral relationship can only be speculated.

In celery we determined that PAL maps to a single chromosomal location. In bean, PAL was found to be encoded by a small family of three genes dispersed in the genome (Cramer et al. 1989). These genes were characterized and found to have diverse nucleotide sequences and this, in addition to their dispersed nature, suggested an ancient evolutionary divergence of PAL genes (Cramer et al. 1989). The closest relative to celery in which PAL has been studied is parsley, where it has been shown to be transcribed in response to UV light and fungal elicitor (Chappell and Hahlbrock 1984). Using copy number reconstructions and sequencing PAL cDNA clones, Lois et al. (1989) found four classes of PAL genes in parsley based on sequence divergence and concluded that PAL is encoded by a small family of at least four genes. Our finding of just a single PAL gene in celery might be explained by divergence of the ancestor of parsley and celery before PAL gene divergence in parsley. Alternatively, PAL genes in celery may have diverged sufficiently so that other loci may have gone undetected using the parsley probe.

Genomic blots of celery DNA show 11 EcoRI fragments hybridizing to the chlorophyll $\mathrm{a} / \mathrm{b}$ binding protein $(\mathrm{pL}$ ) probe, the same number of bands that were revealed by EcoRI in tomato (Pichersky et al. 1985). Two of the bands in celery segregated with null alleles and 1 band, cab-1, was mapped while the other band, $c a b-2$, was unlinked. In tomato, evidence was presented that suggested a recent deletion event of one of the CAB sequences (Pichersky et al. 1985). Null alleles at other loci have been reported (Landry et al. 1987; McCouch et al.
1988; Gebhardt et al. 1989) and suggest a polymorphism due to an insertion/deletion of DNA sequences. Alternatively, the null alleles we observed might be explained by the masking of one allelic band with a monomorphic band.

McCouch et al. (1988) obtained clues to the genetic events leading to restriction polymorphism in rice by comparing the number of enzymes that uncover polymorphism for a single probe. If a polymorphism is caused by a base substitution, the restriction patterns would be affected for only one restriction digest, provided the restriction sites for the different enzymes are independent and do not overlap. If however a deletion/ insertion of DNA base pairs is the basis of a restriction polymorphism, a number of restriction digests would be expected to be affected. In rice, McCouch et al. (1988) determined that the majority of restriction polymorphisms were due to insertion/ deletion of DNA sequences. In celery, the picture is not as clear. Roughly half of the polymorphic clones tested were polymorphic for just 1 enzyme, the rest were polymorphic in more than 1 digest. This suggests that both base substitution and insertion/ deletions might be important sources of the polymorphism we observed.

While no deviation from Mendelian ratios were seen when all loci were pooled, 4 RFLP loci, 1 isozyme locus, and 2 morphological loci showed significant deviations from expected Mendelian ratios (Table 2). In one case, 2 RFLP loci which showed deviation from expected values were linked: $F 34$ and D15 both showed a reduction of heterozygotes and were linked by $6 \mathrm{cM}$. The distortion effect ends at G43, the next RFLP marker on the map $3 \mathrm{cM}$ from F34 (Fig. 3). This suggests that either of the loci, or some gene to which the 2 loci are linked, is somehow involved in selection against the heterozygote. A similar situation involving larger chromosomal regions has been observed in Brassica (McGrath 1991; Kianian 1990).

We are currently in the process of expanding the celery genetic map using randomly amplified polymorphic DNAs (Williams et al. 1991). The markers developed here will serve as a framework for the application of this new generation of genetic markers for saturation of the celery genome. A detailed genetic map will be useful in revealing information about genome organization and can serve in the investigation of phylogenetic relationships between species. These genetic markers will also be useful in tagging important genes for introgression into celery.

Acknowledgements. We are indebted to Vince D'Antonio and Shahyrar F. Kianian for technical assistance and to Nancy Scybert for typing the manuscript. Research supported by grants from the California Celery Research Advisory Board to Carlos F. Quiros.

\section{References}

Anderson CW, Straus JW, Dudock BS (1983) Preparation of a cell-free protein-synthesizing system from wheat germ. Methods Enzymel 101:635-644

Appels R, Gerlach WL, Dennis ES, Swift H, Peacock WJ (1980) Molecular and chromosomal organization of DNA 
sequences coding for the ribosomal RNAs in cereals. Chromosoma 78:293-311

Arus P, Orton TJ (1984) Inheritance patterns and linkage relationships of eight genes of celery. J Hered 75:11-14

Bernatzky R, Tanksley S (1986) Majority of random cDNA probes correspond to single loci in the tomato genome. Mol Gen Genet 203:8-14

Birnboim HC, Doly J (1979) A rapid alkaline extraction procedure for screening recombinant plasmid DNA. Nucleic Acids Res 7:1513

Botstein D, White RL, Skolnick M, Davis RW (1980) Construction of a genetic linkage map in man using restriction length polymorphisms. Am J Hum Genet 32:314-331

Catala G, Savouret J-F, Mendez B, West BL, Karin M, Martial JA, Baxter JD (1983) A method for isolation of intact, translationally active ribonucleic acid. DNA 2:329-335

Chappell J, Hahlbrock K (1984) Transcription of plant defence genes in responce to UV light or fungal elicitor. Nature $311: 76-78$

Cramer CL, Edwards K, Dron M, Liang X, Dildine SL, Boltwell GP, Dixon RA, Schuch W (1989) Phenylalanine ammonialyase gene organization and structure. Plant Mol Biol 12:367-383

de Vilmorin RL (1950) Pascal celery and its origin. J NY Bot Gard 51:39-41

Ellis THN, Lee D, Thomas CM, Simpson PR, Cleary WG, Newman MA, Burcham KWG (1988) 5S rRNA genes in Pisum: sequence, long range and chromosomal organization. Mol Gen Genet 214:333-342

Feinberg A, Vogelstein B (1983) A technique for radiolabeling DNA restriction endonuclease fragments to high specific activity. Anal Biochem 132:6-13

Fisher RL, Goldberg RB (1982) Structure and flanking regions of soybean seed protein genes. Cell 13:277-284

Gebhardt C, Ritter E, Debner T, Schachtschabel U, Walkemeier B, Uhrig, Salamini F (1989) RFLP analysis and linkage mapping in Solanum tuberosum. Theor Appl Genet 78:65-75

Gerlach WL, Bedbrook JR (1979) Cloning and characterization of ribosomal genes from wheat and barley. Nucleic Acid Res 7:1869-1885

Gerlach WL, Dyer TA (1980) Sequence organization of the repeating units in the nucleus of wheat which contain $5 \mathrm{~S}$ rRNA genes. Nucl Acids Res 8:4851-4865

Guber U, Hoffman BJ (1983) A simple and very efficient method for generating cDNA libraries. Gene 25:263-269

Havey MJ, Muehlbauer (1989) Linkages between restriction fragment length, isozyme, and morphological markers in lentil. Theor Appl Genet 77:395-401

Hemleben V, Werts D (1988) Sequence organization and putative regulatory elements in the $5 \mathrm{~S}$ rRNA genes of two higher plants (Vigna radiata and Matthiola incana). Gene 62:165-169

Kianian SF (1990) Evolutionary trends in the Brassica oleracea cytodeme; chromosomal and linkage relationships. $\mathrm{PhD}$ thesis, University of California, Davis, Calif.

Landry BS, Kesseli R, Hei Leung, Michelmore RW (1987) Comparison of restriction endonucleases and sources of probes for their efficiency in detecting restriction length polymorphisms in lettuce (Lactuca sativa L.). Theor Appl Genet 74:646-653

Lapitan NLV, Ganal MV, Tanksley SD (1991) Organization of the $5 \mathrm{~S}$ ribosomal RNA genes in the genome of tomato. Genome 34:509-514

Lois R, Dietrich A, Hahlbrock K, Schultz W (1989) A phenylalanine ammonia-lyase gene from parsley: Structure, regulation and identification of elicitor and light responsive cis-acting elements. EMBO J 8:1641-1648
Maniatis T, Fritsch EF, Sambrook J (1982) Molecular cloning: a laboratory manual. Cold Spring Harbor Laboratory Press, Cold Spring Harbor, N.Y.

Mascia PN, Rubenstein I, Phillips RL, Wang AS, Xiang LZ (1981) Localization of the 5S rRNA genes and evidence for diversity in the $5 \mathrm{~S}$ region of maize. Gene $15: 7-20$

McCouch SR, Kochert G, Yu ZH, Wang ZY, Khush GS, Coffman WR, Tanksley SD (1988) Molecular mapping of rice chromosomes. Theor Appl Genet 76:815-829

McGrath JM, Quiros CF (1991) Inheritance of isozyme and RFLP loci in Brassica campestris and comparison with $B$. oleracea. Theor Appl Genet 82:668-673

McGrath JM, Quiros CF, Harada JJ, Laundry BS (1990) Identification of Brassica oleracea monosomic alien chromosome addition lines with molecular markers reveals extensive gene duplication. Mol Gen Genet 23:198-204

Murray MG, Thompson W (1980) Rapid isolation of highmolecular-weight plant DNA. Nucleic Acid Res 8:42344325

Murray MG, Hoffman LM, Jarvis NP (1983) Improved yield of full-length phaseolin cDNA clones by controlling premature anticomplementary DNA synthesis. Plant Mol Biol 2:75-84

Ochoa O, Quiros CF (1989) Apium wild species: novel sources for resistance to late blight in celery. Plant Breed $102: 317-321$

Orton TJ, Hulbert SH, Durgan ME, Quiros CF (1984) UC1, Fusarium Yellow-resistant celery breeding line. Hort Science 19:594

Pichersky E, Bernatzky R, Tanksley SD, Breidenbach RB, Kausch AP, Cashmore AR (1985) Molecular characterization and genetic maping of two clusters of genes encoding chlorophyll alb-binding proteins in Lycopersicon esculentum (tomato). Gene 40:247-258

Quiros CF, Douches D, D'Antonio (1987a) Inheritance of annual habit in celery: cosegregation with isozyme and anthocyanin markers. Theor Appl Genet 74:203-208

Quiros CF, McGrath M, Stites J (1987b) Use of stem proteins for the identification of celery varieties. Plant Cell Rep $6: 114-117$

Slocum MK, Figdore SS, Kennard WC, Suzuki JY, Osborn TC (1990) Linkage arrangement of restriction fragment length polymorphism loci in Brassica oleracea. Theor Appl Genet $80: 57-64$

Suiter K, Wendal J, Case J (1983) LINKAGE-1: a PASCAL computer program for the detection and analysis of genetic linkage. J Hered 74:203-204

Tanksley SD, Young ND, Paterson AH, Bonierbale MW (1989) RFLP mapping in plant breeding: new tools for an old science. Bio/technology 7:257-264

Trumble JT, Quiros CF (1988) Antixenotic and antibiotic resistance in Apium species to Liriomyza trifolii (Diptera: Agromyzidae). J Econ Entomol 81:602-607

Vallejos CE (1983) Enzyme activity staining. In: Tanksley SD, Orton TJ (eds) Isozymes in plant genetics and breeding, vol A. Elsevier, Amsterdam, pp 469-516

Wiliams JGK, Kubelik AR, Livak KJ, Rafalski JA, Tinget S (1991) DNA polymorphisms by arbitrary markers are useful as genetic markers. Nucleic Acid Res 18:6531-6535

Young ND, Tanksley SD (1988) Restriction fragment length polymorphism maps and the concept of graphical genotypes. Theor Appl Genet 77:95-101

Young ND, Tanksley SD (1989) RFLP analysis of the size of chromosomal segments retained around the $T M-2$ locus of tomato during backcross breeding. Theor Appl Genet $77: 353-359$ 